\title{
What place for social sciences?
}

\section{Lord Rothschild's enquiry into the British Social Science Research Council seems to be complete but the report has not yet been written. Here is what he should conclude:}

In many places social science is regarded as integral with science itself, under some such name as Wissenschaft. In Britain, by contrast, the social sciences have been regarded as studies apart and as studies that are inherently poor relations of the natural sciences. There has been a research council to support academic research in the social sciences for only the past two decades. During that period the Social Science Research Council has earned a mixed reputation. Like its counterparts elsewhere, it has found that many of the projects it has been supporting can easily be made fun of. It has also - and openly - proclaimed that part of its task has been to improve the quality of academic research in the social sciences. (In the process, inevitably, some of its functionaries have been persuaded to laughable pedantry.) Then, with the expectation that research should be useful, the research council had been asked insistently the old utilitarian question, "what use is it?". Nobody knows just which of these views persuaded Sir Keith Joseph, the Secretary of State for Education and Science, to let it be known that he is sceptical of the council and most of its works and, soon after his own appointment last September, to saddle Lord Rothschild with the task of pronouncing on the council's future. Perhaps he was simply counting on the likelihood that the man who caused ructions among natural scientists with his recommendations in 1971 for the reorganization of the other research councils would be equally subversive in the social sciences.

What, however, should he say? The first need is to recognize that the abolition of the Social Science Research Council would be intolerable. Whatever its hesitancy in the past two decades and its ways of working, the council has not merely established a number of important and productive academic groups in British universities, but it has substantially achieved that part of its programme intended to improve the quality of research in the social sciences. Moreover, especially at a time when the universities as such are less able than ever before to support research, the abolition of such a serious fund as the research council has become would create much more damage than the universities could sustain.

So, should the Social Science Research Council be reorganized in some way, and if so, how? In the past three years the council has been doing everything it could to make its procedures more understandable to those whose work it supports and at the same time to make its intentions more widely appreciated by the government and in the country at large. In the process the council has angered many of those who had grown used to the old procedures. Thus the council now finds that its critics are in two camps - those who preferred the past, and those who are unconvinced that its present procedures will deliver what people expect of the social sciences.

Nobody should be dismayed that this turn of events has come about. Who asks that a newly created organization such as the council should be able, within a couple of decades, to find a sure

\section{US contributors please note}

From now on, authors in the United States and Canada should send their manuscripts either direct to London or to the Washington office, whose new address in Nature, 991 National Press Building, Washington, DC 20045; manuscripts should no longer be sent to Nature's New York office. way of supporting research in the social sciences? The problems, acknowledged by everyone concerned at the outset, are too serious for that. And in any case, the successes in the council's portfolio of previously supported projects are quite sufficient to outweigh the hasty criticisms of those who point to projects that have failed. If some reorganization of the social sciences is needed, and it may be, attention should be directed to the present mismatch between what the council does in the support of academic research and the uses which government departments make of academic skill and research in the social sciences.

One of the most valuable parts of Lord Rothschild's declaration on the Social Science Research Council will undoubtedly be the calculation he will have made of the amount of research in universities commissioned directly by government departments and that supported by the research council. Paradoxically, the circumstances are the inverse of those that stimulated Lord Rothschild's recommendation of 1971 for the natural sciences. There, a decade ago, research councils such as those responsible for agriculture and medicine were free to decide for themselves what research strategy should be pursued, while the ministries most directly concerned were able only in passing to offer advice. The recommendation, immediately accepted by the Heath government, that in future (as now) the ministries should commission research in important areas from the research councils was sensible. The fact that the "customer-contractor" principle has not worked entirely satisfactorily is no fault of the principle, but of those who have tried to apply it. In the social sciences, on the other hand, the volume of research commissioned directly by government departments is far greater than that which the Social Science Research Council is able to support. Moreover, on the face of things, the projects commissioned directly by government ministries are put out to academic research groups with comparatively little advice from the Social Science Research Council, the body best equipped to tender an informed opinion. So is there not in the future organization of the Social Science Research Council, a need that the whole volume of public support for research in the social sciences should be channelled through some common agency?

The question remains of what should be the relationship between the social and the natural sciences. Academics, notoriously hide-bound, have over decades argued the toss about the place that social science should occupy in academic life. Economics is accepted, now, as an inevitable part of the spectrum of what goes on in universities. More esoteric subjects anthropology on the one hand, sociology on the other hand - are more easily scorned, but wrongly. Physicists may hold that the data on which people in these disciplines base their arguments, and the arguments themselves, are fuzzy by the standards that apply in, say, the analysis of data collected in some objective measurement of the real world. But was there not a time when even physics was a fuzzy field of speculation? Can it be right that the natural sciences should continue to laugh at the difficulties with which the social sciences must contend? For what the field needs is what the Social Science Research Council has been saying for the past twenty years is an essential part of its own brief - the general improvement of methods of teaching as well as of research that will, in due course, make social science accessible to a wider circle, and thus more useful. 